\title{
PENURUNAN KEKERUHAN, KADAR LAS DAN FOSFAT LIMBAH CUCIAN RUMAH TANGGA DENGAN METODE KOMBINASI PENGOLAHAN KOAGULASI DAN PROSES OKSIDASI LANJUT SISTEM UV/ $\mathrm{H}_{2} \mathrm{O}_{2}$
}

\author{
I Made Candra Wiguna ${ }^{1}$, Ni Wayan Yuningrat ${ }^{2}$, I Made Gunamantha ${ }^{3}$ \\ Universitas Pendidikan Ganesha \\ Singaraja, Indonesia \\ e-mail: cndraimw@gmail.com ${ }^{1}$, wyyuniingrat@gmail.com ${ }^{2}$, \\ md_gunamantha@yahoo.com ${ }^{3}$
}

\begin{abstract}
Abstrak
Peneliatian ini adalah penelitian eksperimen yang bertujuan untuk menganalisis kekeruhan, kadar LAS (Linier Alkyl Sulfonate) dan fosfat pada limbah cucian rumah tangga di salah satu pemukiman padat penduduk di kawasan Kota Singaraja sesuai Keputusan Menteri Negara Lingkungan Hidup KEP 51/MENLH/10/1995. Subjek penelitian ini adalah limbah cucian rumah tangga di salah satu pemukiman padat penduduk di kawasan Kota Singaraja, sedangkan objek dari penelitian ini adalah kekeruhan, kadar LAS (Linier Alkyl Sulfonate) dan fosfat. Penelitian ini menggunakan metode koagulasi dengan koagulan $\mathrm{FeCl}_{3}$. Metode koagulasi ini untuk menentukan $\mathrm{pH}$ dan konsentrasi optimum $\mathrm{FeCl}_{3}$ dikombinasikan dengan proses AOP sistem $\mathrm{UV} / \mathrm{H}_{2} \mathrm{O}_{2}$ untuk menurunkan kekeruhan, kadar LAS dan fosfat pada limbah cucian rumah tangga. Sebelum percobaan dilakukan, kekeruhan, kadar LAS dan fosfat ditentukan terlebih dahulu nilai kekeruhan awal limbah cucian rumah tangga tersebut sebelum diberikan perlakuan yaitu $164 \mathrm{NTU}$, kadar LAS awal tanpa perlakuan yaitu 2,659 mg/L, dan kadar fosfatt awal tanpa perlakuan $0,988 \mathrm{mg} / \mathrm{L}$. Kondisi optimum pada proses koagulasi untuk pengolahan limbah cucian rumah tangga dengan penambahan $25 \mathrm{~mL}$ koagulan $\mathrm{FeCl}_{3} 2 \%$ pada $\mathrm{pH} 4$. Efisiensi penurunan kekeruhan LAS dan fosfat berturut-turut pada kondisi tersebut adalah $90,7 \%, 72,9 \%$ dan $89,2 \%$. Efisiensi penurunan kekeruhan, kadar LAS dan fosfat dari proses dengan Proses AOP Sistem UV/ $\mathrm{H}_{2} \mathrm{O}_{2}$ berturut-turut adalah 72,5\% , 93,3\% dan 96,2\% Efisiensi penurunan nilai kekeruhan, kadar LAS dan fosfat dari kombinasi proses koagulasi dan AOP sistem $\mathrm{UV} / \mathrm{H}_{2} \mathrm{O}_{2}$ berturut-turut sebesar $97,4 \%, 98,1 \%$ dan $99,5 \%$.
\end{abstract}

Kata kunci: Limbah Cucian Rumah Tangga, Koagulasi, AOP, dan Efisiensi

\begin{abstract}
This research was aimed to reduce turbiditi, LAS and phosphate in waste household laundry experimentally. The subjct was waste household laundry in one of Singaraja densely populated area. The objects were turbidity value, LAS and phosphate concentration coagulation process using $\mathrm{FeCl}_{3}$ was combineed with Advanced Oxidation process (AOP) in this research. Optimum condition of koagulation process was reached by variation of $\mathrm{pH}$ and $\mathrm{FeCl}_{3}$ concentration. Turbidity value, , LAS and phosphate concentration before using in this research were $164 \mathrm{NTU}, 2,659 \mathrm{mg} / \mathrm{L}$ and $0,988 \mathrm{mg} / \mathrm{L}$. optimum coagulation process was reached at $\mathrm{pH} 4$ and $25 \mathrm{~mL} \mathrm{FeCl} 32 \%$. Turbidity, LAS dan phosphate removal from coagulation process were $90,7 \%, 72,9 \%$, and $89,2 \%$. Removal efficiency of Turbidity, LAS dan phosphate value from AOP UV// $\mathrm{H}_{2} \mathrm{O}_{2}$ system were $72,5 \%, 93,3 \%$, and $96,2 \%$. Combination of koagulation and AOP using in this reached has decreased 90,7\%, turbidity, 98,1 LAS, and 99,5 phosphate in laundry household waste.
\end{abstract}

Keywords: Laundry Household Waste, Coagulation, AOP, and Efficiency 


\section{Pendahuluan}

Deterjen adalah salah satu polutan utama yang terdapat pada air limbah domestik yang dihasilkan dari tingkat rumah tangga. Komponen utama deterjen adalah surfaktan, penguat (builders), dan aditif. Surfaktan merupakan bahan pembersih utama dalam deterjen. Surfaktan adalah agen pembersih aktif yang melakukan tiga peran utama: penetrasi dan membasahi kain, melepaskan kotoran (dibantu dengan tindakan mekanis dari mesin), dan sebagai pengemulsi kotoran dan menjaganya tersuspensi dalam cairan cucian. Surfaktan merupakan suatu senyawa aktif penurun tegangan permukaan yang dapat diproduksi melalui sintesis kimiawi maupun biokimiawi. Sifat aktif permukaan yang dimiliki surfaktan diantaranya mampu menurunkan tegangan permukaan, tegangan antar muka dan meningkatkan kestabilan sistem emulsi. Hal ini membuat surfaktan banyak digunakan dalam berbagai industri, seperti industri sabun, deterjen, produk kosmetika dan produk perawatan diri, farmasi, pangan, cat dan pelapis, kertas, tekstil, pertambangan industri perminyakan, dan lain sebagainya (jhonatan 2009).

Selain surfaktan, builder juga memegang peranan penting dalam deterjen. Builder dalam deterjen berfungsi membantu efisensi surfaktan dalam proses pembersihan kotoran. Bahan yang umumnya digunakan sebagai builder adalah tripholy poshate (STTP) artinya fosfat adalah penyusun utama builder.

Berbagai jenis surfaktan dapat digunakan dalam deterjen, namun surfaktan yang biasa digunakan dalam deterjen adalah Alkyl Benzene Sulfonate (ABS) dan Linier Alkyl Sulfonate (LAS). Kedua jenis surfaktan anionik dalam bentuk sulfonat tersebut bila dilarutkan dalam air akan berubah menjadi partikel bermuatan negatif, memiliki daya bersih yang sangat baik, dan biasanya berbusa banyak (umumya digunakan untuk mencuci kain dan piring).

Saat ini konsumsi deterjen di Indonesia telah mencapai 95.000 ton (http://www.ristek.go.id). Dalam Bisnis Indonesia sebagaimana yang dikutip oleh Sopiah (digilib.batan.go.id/e-prosiding/.../r-nida_s_99.pd) dilaporkan bahwa konsumsi deterjen per kapita para tahun 1997 hanya $1,97 \mathrm{~kg}$ namun dengan membaiknya daya beli masyarakat, konsumsi deterjen meningkat menjadi $2,11 \mathrm{~kg}$ per kapita pada tahun 1999 , dan berturut-turut $2,26 \mathrm{~kg}$ dan 2,32 $\mathrm{kg}$ per kapita pada tahun 2001 dan 2002. Sopiah juga menyebutkan bahwa berdasarkan data hasil estimasi Tim Notulen Kantor Lingkungan Daerah (NKLD) DKI Jakarta Tahun 2000 , produksi deterjen per tahun sebanyak 116,80 ribu ton, dengan prediksi volume limbah 327,04 ${\text { ribu } \mathrm{m}^{3} / \text { tahun. }}^{2}$.

Berbagai upaya pengolahan limbah deterjen seperti metode koagulasi telah digunakan secara luas dalam pengolahan air untuk menghilangkan polutan-polutan limbah dalam bentuk tersuspensi atau koloid, menurunkan COD, dan untuk mengendalikan berbagai kontaminan seperti mikroorganisme, partikulat yang menyebabkan kekeruhan dan warna, beberapa bentuk bahan organik alami, dan zat anorganik. Koagulasi lebih efektif untuk menurunkan kekeruhan dengan mengendapkan partikel-partikel dalam bentuk tersuspensi dan koloid. Penurunan bahan-bahan pencemar organik hanya didasarkan pada peluang terikutnya bahan pencemar tersebut mengendap bersama partikel tersuspensi dan koloid. Oleh karena itu, untuk meningkatkan efektifitas penurunan beban organik pada air limbah cucian perlu dikombinasikan dengan proses oksidasi. Khusus untuk beban organik yang tidak mudah dibiodegradasi, proses oksidasi lanjut adalah upaya yang dapat dipertimbangkan untuk mencapai tujuan tersebut.

Teknologi oksidasi kimia atau proses oksidasi lanjut didasarkan pada penggunaan radiasi UV dan oksidan seperti hidrogen peroksida $\left(\mathrm{H}_{2} \mathrm{O}_{2}\right)$ dan ozon $\left(\mathrm{O}_{3}\right)$. Proses ini telah berhasil digunakan dalam remediasi air limbah yang terkontaminasi dengan spektrum polutan organik yang luas. Proses ini bergantung pada pembentukan radikal hidroksil yang mendegradasi kandungan pencemar organik air limbah. Beberapa sistem proses oksidasi lanjut yang telah banyak digunakan adalah $\mathrm{UV} / \mathrm{H}_{2} \mathrm{O}_{2}, \mathrm{O}_{3} / \mathrm{H}_{2} \mathrm{O}_{2}, \mathrm{O}_{3} / \mathrm{UV}$ dan $\mathrm{UV} / \mathrm{H}_{2} \mathrm{O}_{2} / \mathrm{O}_{3}$ (Huang et al. 1993.; Legrini et al.1993;. Prado et al. 1994;. Matthews, 1992; Domenech et al., 2001. Dalam Novi, 2013) Agar proses oksidasi lanjut berlangsung optimal, beberapa faktor utama yang harus dipertimbangkan adalah $\mathrm{pH}$, konsentrasi $\mathrm{H}_{2} \mathrm{O}_{2}$, dan waktu kontak.

Berdasarkan kenyataan tersebut, kombinasi dari proses koagulasi dan proses oksidasi lanjut akan sinergis untuk menurunkan kekeruhan dan kadar surfaktan dalam limbah deterjen. Oleh karena itu, penelitian ini bertujuan untuk menguji efisiensi dari kombinasi koagulasi dan proses oksidasi lanjut dengan sistem $\mathrm{UV} / \mathrm{H}_{2} \mathrm{O}_{2}$ untuk mengurangi kekeruhan, kadar LAS dan fosfat dalam limbah cucian rumah tangga. 


\section{Metode}

Jenis penelitian ini adalah penelitian eksperimen yang bertujuan untuk mengetahui kekeruhan, kadar LAS dan fosfat pada limbah cucian rumah tangga serta efisiensi penurunan kekeruhan kadar LAS dan Fosfat pada limbah cucian rumah tangga yang berlokasi di Daerah Singaraja dengan kombinasi koagulasi dengan koagulan feri klorida $\left(\mathrm{FeCl}_{3}\right)$ dan sistem fotokimia $\mathrm{UV} / \mathrm{H}_{2} \mathrm{O}_{2}$. Tahap penelitian ini meliputi pengambilan sampel, analisis kadar deterjen dan kekeruhan serta efisiensi penurunannya dengan kombinasi koagulan feri klorida $\left(\mathrm{FeCl}_{3}\right)$ dan sistem fotokimia $\mathrm{UV} / \mathrm{H}_{2} \mathrm{O}_{2}$ dengan menggunakan spektrofotometer, dan pelaporan hasil. Sampel ditentukan pada rumah tangga yang mengalirkan limbah cucian hasil kegiatan rumah tangga langsung ke lingkungan atau badan air

Alat utama yang digunakan dalam penelitian adalah sebagai berikut: Turbidimeter (Shimadzu 1601), jar test, spektrofotometer, reaktor AOP yang dilengkapi dengan 5 buah lampu UV (Sangyo Denki Blacklight Blue 352nm 10W).

Bahan utama yang digunakan dalam penelitian ini yaitu larutan baku deterjen yaitu natrium lauril sulfat $\left(\mathrm{C}_{12} \mathrm{H}_{25} \mathrm{OSO}_{3} \mathrm{Na}\right)$, larutan indikator fenolftalin $0,5 \%$, larutan natirum hidroksida, larutan metilen blue, larutan pencuci, larutan ammonium molibdat, larutan $\mathrm{SnCl}_{2} .2 \mathrm{H}_{2} \mathrm{O}, \mathrm{H}_{2} \mathrm{O}_{2} 30 \%$ dan koagulan $\left(\mathrm{FeCl}_{3}\right) 2 \%$. Adapun prosedur dalam penelitian ini yaitu:

\section{A. Tahapan Koagulasi}

Tahapan koagulasi dilakukan dengan 2 tahapan yaitu tahapan penentuan $\mathrm{pH}$ optimum pada sampel dan tahapan penentuan turbiditas terendah. Tahapan penentuan $\mathrm{pH}$ optimum dilakukan dengan prosedur sebagai berikut : (1) Disiapkan alat dan bahan yang akan digunakan. 2) 6 gelas beker diisi masing-masing $500 \mathrm{~mL}$ sampel limbah dengan $\mathrm{pH}$ masingmasing sampel berbeda yaitu $\mathrm{pH} 4,5,6,7,8$, dan 9. (3) Masing-masing sampel ditambahkan kogulan feri klorida $\left(\mathrm{FeCl}_{3}\right) 2 \%$ dengan konsentrasi 5, 10, 15, 20, 25, dan $30 \mathrm{~mL}$. (4) Sampel dilakukan proses koagulasi dengan pengadukan cepat dengan kecepatan $160 \mathrm{rpm}$ selama 5 menit dan pengadukan lambat dengan kecepatan $30 \mathrm{rpm}$ selama 20 menit. (5) Sampel didiamkan selama 30 menit kemudian sampel dilakukan pengujian kekeruhan. (6) Kekeruhan dari masing-masing sampel ditentukan dengan turbidimeter.

Setelah mengetahui $\mathrm{pH}$ optimum pada sampel maka dilanjutkan dengan penentuan nilai turbiditas terendah untuk konsentrasi koagulan yang optimum dengan prosedur penelitian yaitu sebagai berikut : (1) Disiapkan alat dan bahan yang akan digunakan. (2) 6 gelas beker diisi masing-masing $500 \mathrm{~mL}$ sampel limbah dan $\mathrm{pH}$ masing-masing sampel diatur sesuai dengan $\mathrm{pH}$ optimum. (3) Masing-masing sampel ditambahkan kogulan feri klorida $\left(\mathrm{FeCl}_{3}\right)$ dengan volume $5,10,15,20,25$ dan $30 \mathrm{~mL}$. (4) Sampel dilakukan proses koagulasi dengan pengadukan cepat dengan kecepatan $160 \mathrm{rpm}$ selama 5 menit dan pengadukan lambat dengan kecepatan 30 rpm selama 20 menit. (5) Sampel didiamkan selama 30 menit kemudian sampel difiltasi dan filtrat tersebut dilakukan pengujian kekeruhan . (6) kekeruhan dari masing-masing sampel ditentukan dengan turbidimeter.

Dengan didapatkannya $\mathrm{pH}$ dan konsentrasi koagulan optimum maka akan dilanjutkan dengan persiapan sampel untuk Proses Oksidasi Lanjut (AOP) dengan prosedur penelitian sebagai berikut : (1) Disiapkan alat dan bahan yang akan digunakan. (2) 6 gelas beker diisi masing-masing $500 \mathrm{~mL}$ sampel limbah dan $\mathrm{pH}$ masing-masing sampel diatur sesuai dengan $\mathrm{pH}$ optimum. (3) Masing-masing sampel ditambahkan feri klorida $\left(\mathrm{FeCl}_{3}\right)$ sesuai dengan konsentrasi koagulan optimum. (4) Sampel dilakukan proses koagulasi dengan pengadukan cepat dengan kecepatan $160 \mathrm{rpm}$ selama 5 menit dan pengadukan lambat dengan kecepatan 30 rpm selama 20 menit. (5) Sampel didiamkan selama 30 menit kemudian sampel difiltasi dan filtrat tersebut dilakukan pengujian turbiditas dan kadar deterjen. (6) kekeruhan dari masingmasing sampel ditentukan dengan turbidimeter.

\section{B. Tahapan AOP sistem $\mathrm{UV} / \mathrm{H}_{2} \mathrm{O}_{2}$.}

(1) Disiapkan alat dan bahan yang akan digunakan. (2) Penelitian ini dilakukan pada suhu ruangan. Keenam sampel limbah yang telah diberi perlakuan $\mathrm{pH}$ dan konsentrasi koagulan optimum pada proses sebelumnya dimasukkan ke dalam tabung reaktor kemudian ditambahkan $\mathrm{H}_{2} \mathrm{SO}_{4} 95 \%$ sampai pH 3. (3) Setelah itu pada setiap sampel ditambahkan $\mathrm{H}_{2} \mathrm{O}_{2}$ dengan volume $0 \mathrm{~mL}, 5 \mathrm{~mL}, 10 \mathrm{~mL}, 15 \mathrm{~mL}, 20 \mathrm{~mL}$, dan $25 \mathrm{~mL}$. (4) Tabung diinstalasi pada rangkaian reaktor dan tabung ditutup dengan aluminium foil. Rangkaian reaktor diletakkan di atas magnetic stirrer. (5) Magnetic stirrer dijalankan dan kemudian disinari dengan lampu UV 
selama 2 jam, kemudian reaksi dihentikan untuk dilakukan pemeriksaan kekeruhan ,kadar LAS dan fosfat . (6) Sampel disinari dengan lampu UV dengan waktu kontak masing-masing 2 jam.

\section{Pemeriksaan kekeruhan}

Pemeriksaan kekeruhan setelah proses AOP sistem $\mathrm{UV} / \mathrm{H}_{2} \mathrm{O}_{2}$ dilakukan dengan menggunakan turbidimeter. Sampel dimasukkan kedalam alat dan hasil pemeriksaan langsung dibaca dan tertera pada layar turbidimeter.

\section{Tahap Pemeriksaan Kadar LAS}

1. Pembuatan kurva kalibrasi

(1) 1,00 gram baku LAS ditimbang dan dilarutkan dengan air suling sampai $1000 \mathrm{~mL}$. (2) 10,00 mL larutan induk LAS diencerkan sampai $1000 \mathrm{~mL}$ air suling. (3) Dibuat satu seri yang terdiri dari sepuluh larutan baku dari 0,$0 ; 1,00 ; 3,00 ; 5,00 ; 7,00 ; 9,00 ; 11,00 ; 13,00 ; 15,00$; dan $20,00 \mathrm{~mL}$ larutan baku dan ditambahkan air suling sampai volume $100 \mathrm{~mL}$.

\section{Pengujian kadar LAS pada Deterjen}

Sampel limbah pada proses koagulasi dan proses fotokimia $\mathrm{UV} / \mathrm{H}_{2} \mathrm{O}_{2}$ sebelum dilakukan perlakuan dan sesudah ditentukan kadar LAS dengan menggunakan metode metilen blue dengan prosedur kerja sebagai berikut :

(1) Disiapkan alat dan bahan yang akan digunakan. (2) Sebanyak $25 \mathrm{~mL}$ sampel dimasukkan ke dalam corong pemisah $250 \mathrm{~mL}$ pertama. (3) Kemudian ditambahkan 2 tetes indikator fenolftalain dan tetes demi tetes larutan $\mathrm{NaOH} 1 \mathrm{~N}$ ke dalam sampel sampai berubah menjadi warna merah muda. (4) Sampel ditambahkan tetes demi tetes $\mathrm{H}_{2} \mathrm{SO}_{4}$ sampai berwarna bening. ditambah dengan larutan metilen biru sebanyak $6,25 \mathrm{~mL}$ dan 2,5 $\mathrm{mL}$ kloroform yang kemudian dikocok selama 30 detik. Tutup corong dibuka untuk mengeluarkan gas. (5) Setelah itu ditambah dengan $2,5 \mathrm{~mL}$ propanol yang kemudian dikocok kembali sampai terbentuk 2 (dua) lapisan. Lapisan bawah dipisahkan dan dipindahkan pada corong pemisah kedua. Pada corong pisah pertama dilakukan ekstraksi kembali dengan penambahan kloroform sampai tidak terbentuk 2 (dua) lapisan pada sampel. Jika masih terbentuk 2 (dua) lapisan maka lapisan bawah kembali dipisahkan dan dipindahkan pada corong pisah kedua. (6) Pada corong pisah kedua ditambahkan larutan pencuci sebanyak $12,5 \mathrm{~mL}$ yang kemudian dikocok selama 30 detik. Corong pisah dibiarkan sampai terjadi pemisahan fasa. Setelah itu lapisan bawah dikeluarkan dan dimasukkan ke dalam labu ukur. Corong pisah kedua diekstraksi kembali dengan menambahkan $5 \mathrm{~mL}$ kloroform dan dimasukkan pada labu ukur. Kemudian labu ukur ditambah dengan kloroform sampai batas garis labu ukur dan dikocok hingga homogen. Absorbansinya diukur pada panjang gelombang $652 \mathrm{~nm}$.

\section{E. Tahap Pemeriksaan Kadar Fosfat}

1. Pembuatan kurva kalibrasi

(1) Larutan baku fosfat dibuat dengan konsentrasi 0,$0 ; 0,2 ; 0,4 ; 0,6 ; 0,8 ; 1,0 ; 1,2 ; 1,4$; 1,$6 ; 1,8 \mathrm{mg} / \mathrm{L}$. (2) $10,0 \mathrm{~mL}$ larutan baku fosfat dipipet kemudian diencerkan dengan akuades sampai $50,0 \mathrm{~mL}$.

\section{Pengujian Kadar Fosfat Pada Deterjen}

Sampel limbah pada proses koagulasi dan proses fotokimia $\mathrm{UV} / \mathrm{H}_{2} \mathrm{O}_{2}$ dilanjutkan penentuan kadar fosfat dengan menggunakan dengan prosedur kerja sebagai berikut : (1) Disiapkan alat dan bahan yang akan digunakan. (2) Sebanyak $100 \mathrm{~mL}$ sampel ditambahkan 4 $\mathrm{mL}$ molibdat dan $0,5 \mathrm{~mL} \mathrm{SnCl}_{2} 2 \mathrm{H}_{2} \mathrm{O}$. Diamkan selama 10 menit hingga homogen. (3) Absorbansinya diukur pada panjang gelombang $690 \mathrm{~nm}$.

Data yang dikumpulkan berupa data kuantitatif tentang penurunan nilai kekeruhan, kadar LAS dan fosfat serta efisiensi kombinasi proses koagulasi dengan proses AOP sistem $U V / \mathrm{H}_{2} \mathrm{O}_{2}$ pada limbah cucian rumah tangga yang diambil pada salah satu pemukiman padat penduduk di daerah Singaraja. Pemeriksaan nilai kekeruhan dilakukan dengan menggunakan alat Turbidimeter. Sampel dimasukkan kedalam alat dan hasil pemeriksaan langsung dibaca dan tertera pada layar turbidimeter, sedangkan untuk pemeriksaan kadar LAS dilakukan dengan metode metilen biru dan pemeriksaan kadar fosfat dilakukan pemeriksaan dengan metode stano klorida yang masing-masing diukur absorbansinya dengan menggunakan spektrofotometer UV-Vis single beam. 
Data yang diperoleh dari hasil penelitian ini adalah nilai dari parameter kekeruhan, kadar LAS dan fosfat pada sampel limbah cucian rumah tangga Nilai tersebut kemudian disajikan menggunakan tabel dan grafik yang dianalisis secara deskriptif. Tabel dan grafik yang dibuat menyajikan pengaruh koagulan feri klorida dan penambahan $\mathrm{H}_{2} \mathrm{O}_{2}$ terhadap efisiensi penurunan kekeruhan, kadar LAS dan fosfat pada limbah cucian rumah tangga. Efisiensi penurunan kekeruhan dan deterjen ditentukan berdasarkan pada selisih antara kadar awal dengan kadar akhir terhadap kadar awal, dapat dihitung dengan persamaan sebagai berikut :

Keterangan :

$$
\text { eff }=\frac{[A]_{0}-[A]_{t}}{[A]_{0}} \times 100 \%
$$

$$
\begin{aligned}
& A_{0}=\text { Konsentrasi awal } \\
& A_{t}=\text { Konsentrasi akhir } \\
& \text { eff }=\text { Efisiensi parameter uji }
\end{aligned}
$$

\section{Hasil dan Pembahasan}

Sebelum percobaan dilakukan, ditentukan terlebih dahulu nilai kekeruhan awal limbah cucian rumah tangga tersebut sebelum diberikan perlakuan yaitu 164 NTU, kadar deterjen awal tanpa perlakuan yaitu $2,659 \mathrm{mg} / \mathrm{L}$, dan kadar fosfat awal tanpa perlakuan $0,988 \mathrm{mg} / \mathrm{L}$. Air cucian rumah tangga atau air limbah domestik mempunyai baku mutu yaitu ukuran batas atau kadar unsur pencemar dalam air limbah, yang akan dibuang atau dilepas ke perairan atau air permukaan. Sebelum dibuang ke perairan atau saluran pembungan air limbah tersebut harus diolah terlebih dahulu di IPAL (Instalasi pengolahan air limbah) sampai memenuhi baku mutu yang ditetapkan oleh pemerintah. Kadar maksimum kekeruhan yang diperbolehkan menurut standar baku mutu limbah cair domestik yaitu 6 sampai 9 NTU. Pada LAS dan fosfat kadar maksimum yang diperbolehkan yaitu 5,0 sampai $10 \mathrm{mg} / \mathrm{L}$ Berdasarkan Keputusan Menteri Negara Lingkungan Hidup nomor KEP 51/MENLH/10/1995. Dari data yang diperoleh menunjukkan bahwa limbah cucian rumah tangga yang digunakan dalam penelitian ini tidak melebihi baku mutu dan layak untuk dilepas ke lingkungan. Akan tetapi jika persentase limbah cucian rumah tangga yang dilepas ke lingkungan semakin bertambah, maka akan membahayakan alam dan lingkungan itu sendiri. Jadi perlu dilakukannya pengolahan limbah cair domestik agar kerusakan lingkungan akibat bertambahnya persentase pembuangan limbah ke lingkungan bisa dikurangi.

\section{A. Penurunan Nilai Kekeruhan dan Efisiensi Penurunan Nilai Kekeruhan, Kadar LAS, dan Fosfat Pada Proses Koagulasi}

Hasil pengujian nilai kekeruhan limbah cucian rumah tangga disajikan pada Tabel 1.

Tabel 1. Hasil Penurunan dan Efisiensi Penurunan Nilai kekeruhan dari Proses Koagulasi

\begin{tabular}{ccccc}
\hline No. & Jenis Sampel & $\begin{array}{c}\text { Sampel Sebelum } \\
\text { Perlakuan (NTU) }\end{array}$ & Hasil (NTU) & Efisiensi (\%) \\
\hline 1. & K31 & 164 & 15,3 & 90,6 \\
2. & K32 & 164 & 15,8 & 90,3 \\
3. & K33 & 164 & 14,9 & 90,9 \\
4. & K34 & 164 & 15,1 & 90,7 \\
5. & K35 & 164 & 14,7 & 91 \\
6. & K36 & 164 & 15,2 & 90,7 \\
\hline \multicolumn{6}{r}{ Rata-Rata } & 164 & $\mathbf{1 5 , 1}$ & 90,7 \\
\hline SD & - & - & $\mathbf{0 , 0 3}$ \\
\hline
\end{tabular}


Tabel 2. Hasil Pengamatan Penurunan Kadar LAS dan Fosfat dari Proses Koagulasi

\begin{tabular}{ccccc}
\hline No & Parameter Pengukuran Sample & $\begin{array}{c}\text { Sampel Sebelum } \\
\text { Perlakuan }(\mathbf{m g} / \mathbf{L})\end{array}$ & $\begin{array}{c}\text { Sampel } \\
\text { Setelah } \\
\text { Perlakuan } \\
(\mathbf{m g} / \mathbf{L})\end{array}$ & $\begin{array}{c}\text { Efisiensi } \\
(\%)\end{array}$ \\
\hline 1. & LAS & 2,659 & 0,720 & 72,9 \\
2. & Fosfat & 0,988 & 0,106 & 89,2 \\
\hline
\end{tabular}

Berdasarkan Tabel 2, diperoleh hasil kombinasi $\mathrm{pH}$ optimum dan dosis optimum dengan efisiensi penurunan nilai kekeruhan yang dirata-ratakan yaitu sebesar $90,7 \%$. Dari data tersebut dilanjutkan dengan menghitung standar deviasi (SD) dan relatif standar deviasi (RSD) untuk mengetahui kehomogenan data. Hasil perhitungan yang diperoleh untuk SD yaitu 0,03 sedangkan untuk RSD 0,27\%. Dilihat dari SD yang didapatkan maka terlihat bahwa data dari proses koagulasi dengan $\mathrm{pH}$ optimum dan konsentrasi koagulan optimum mendekati kehomogenan atau data penelitian memiliki nilai identik. Karena jika nilai standar deviasi 0 (nol), ini menunjukkan data pengamatan homogen, semua memiliki nilai identik. Semakin besar nilai SD, menunjukkan data memiliki kecendrungan setiap data berbeda satu sama lain, sedangkan nilai RSD yang baik $<2 \%$. Oleh karena itu nilai dari proses koagulasi dengan $\mathrm{pH}$ optimum dan konsentrasi koagulan optimum memiliki nilai RSD yang baik. Nilai RSD dinyatakan untuk menggambarkan presisi (ketepatan) maka dengan presisi yang tinggi memberikan makna bahwa penelitian tersebut dilakukan dengan tingkat kesalahan yang kecil.

Proses koagulasi pada $\mathrm{pH}$ optimum dan konsentrasi optimum telah terjadi penurunan nilai kekeruhan, penurunan tersebut diakibatkan pada proses koagulasi terjadi destabilisasi koloid dan partikel dalam air dari pengadukan cepat dan pembubuhan bahan kimia (koagulan). Akibat pengadukan cepat, koloid dan partikel yang stabil berubah menjadi tidak stabil karena terurai menjadi partikel yang bermuatan positif dan negatif. Pembentukan ion positif dan negatif juga dihasilkan dari proses penguraian koagulan. Setelah terbentuk inti flok, diikuti oleh proses flokulasi, yaitu penggabungan inti flok menjadi flok berukuran lebih besar yang memungkinkan partikel dapat mengendap.

Hasil pengamatan kadar LAS dan fosfat dari proses koagulasi dapat dilihat pada Tabel 4.9 di atas. Kadar LAS pada tahap ini terjadi penurunan kadar dari 2,659 mg/L menjadi 0,720 $\mathrm{mg} / \mathrm{L}$ dengan efisiensi penurunan kadar LAS sebesar $72,9 \%$, sedangkan kadar fosfat dari proses koagulasi terjadi penurunan kadar dari $0,988 \mathrm{mg} / \mathrm{L}$ menjadi $0,106 \mathrm{mg} / \mathrm{L}$ dengan efisiensi penurunan kadar fosfat sebesar $89,2 \%$. Efisiensi penurunan kadar LAS dan fosfat dari proses koagulasi kurang memberikan efisiensi penurunan yang baik dibandingkan dengan efisiensi penurunan pada nilai kekeruhan.

\section{B. Penentuan Nilai Kekeruhan, LAS dan Fosfat Pada Proses AOP Sistem UV/ $\mathrm{H}_{2} \mathrm{O}_{2}$}

Pada proses koagulasi setelah didapatkan $\mathrm{pH}$ dan konsentrasi optimum. Maka untuk tahap selanjutnya dilakukan proses $A O P$ sistem $\mathrm{UV} / \mathrm{H}_{2} \mathrm{O}_{2}$. Hasil pengamantan nilai kekeruhan dan efisiensi penurunan nilai kekeruhan dari proses koagulasi, AOP sistem $\mathrm{C}$ dan dari kombinasi proses koagulasi dan AOP sistem UV/ $\mathrm{H}_{2} \mathrm{O}_{2}$ disajikan dalam Tabel 3

Tabel 3. Hasil Pengamatan Nilai Kekeruhan dari Proses Koagulasi

\begin{tabular}{ccccc}
\hline No. & $\begin{array}{c}\text { Sampel Setelah Proses } \\
\text { AOP } \\
\text { (NTU) }\end{array}$ & $\begin{array}{c}\text { Efisinsi dengan } \\
\text { Proses Koagulasi } \\
(\%)\end{array}$ & $\begin{array}{c}\text { Efisiensi } \\
\text { Setelah } \\
\text { Proses AOP } \\
(\%)\end{array}$ & $\begin{array}{c}\text { Efisiensi } \\
\text { Kombi Nasi } \\
\text { Proses } \\
\text { Koagu Lasi } \\
\text { dan AOP } \\
(\%)\end{array}$ \\
\hline 1 & 10,2 & 90,7 & 32,4 & 93,7 \\
2 & 6,19 & 90,7 & 59 & 96,2 \\
3 & 6.13 & 90,7 & 59,4 & 96,2 \\
4 & 5,9 & 90,7 & 60,9 & 96,4 \\
5 & 4,83 & 90,7 & 68 & 97 \\
6 & 4,15 & 90,7 & 72,5 & 97,4 \\
\hline
\end{tabular}


Berdasarkan Tabel 3, sebelum proses koagulasi, ditentukan terlebih dahulu nilai kekeruhan awal limbah cucian rumah tangga tersebut. yaitu sebesar 164 NTU. Setelah proses koagulasi, terjadi penurunan nilai kekeruhan yaitu sebesar 15,1 NTU. Pada tahap koagulasi mengalami penurunan nilai kekeruhan sebanyak 148 NTU. Setelah proses AOP nilai kekeruhan mengalami penurunan dari 15,1 menjadi 4,15 NTU atau turun sebesar 10,9 NTU pada penambahan volume $25 \mathrm{~mL} \mathrm{H}_{2} \mathrm{O}_{2}$ pengolahan limbah cucian rumah tangga dengan kombinasi proses koagulasi dan AOP sistem UV/ $\mathrm{H}_{2} \mathrm{O}_{2}$ dapat menurunkan nilai kekeruhan sebanyak 156 NTU dari kadar awal 164 NTU.

Diagram efisiensi penurunan kekeruhan dari proses koagulasi, AOP sistem UV/ $\mathrm{H}_{2} \mathrm{O}_{2}$ dan dengan kombinasi proses koagulasi dan AOP sistem UV/ $\mathrm{H}_{2} \mathrm{O}_{2}$. disajikan pada Gambar 1 .

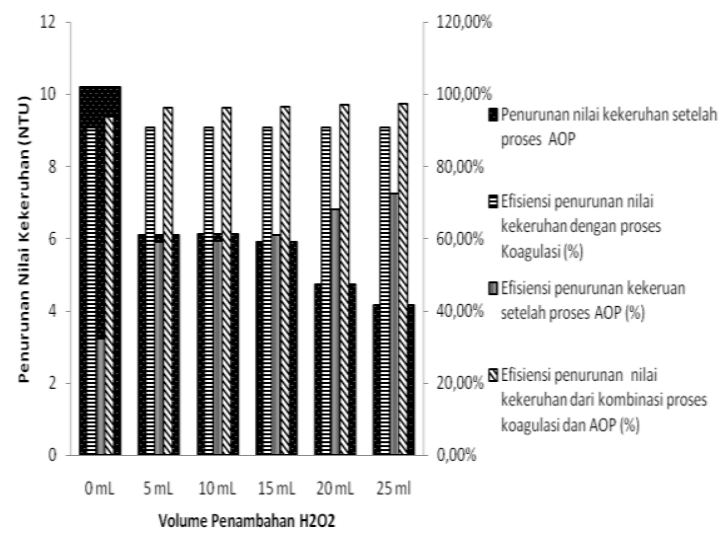

Gambar 1. Diagram Efisiensi Penurunan Nilai Kekeruhan dari Proses Koagulasi

Dilihat dari Gambar 1, dibuktikan bahwa telah terjadi penurunan nilai kekeruhan pada limbah cucian rumah tangga yang diolah dengan menggunakan variasi $\mathrm{pH}$ dan dosis optimum dengan proses koagulasi dan proses AOP sistem $\mathrm{UV} / \mathrm{H}_{2} \mathrm{O}_{2}$ pada $\mathrm{pH}$ 3. Dari data tersebut, diperoleh kondisi maksimum penurunan nilai kekeruhan limbah cucian rumah tangga dari proses koagulasi dengan efisiensi penurunan nilai kekeruhan 90,7\%, Efisiensi penurunan nilai kekeruhan maksimum dari proses AOP sistem $\mathrm{UV} / \mathrm{H}_{2} \mathrm{O}_{2}$ yaitu sebesar $72,5 \%$, dan efisiensi penurunan nilai kekeruhan dari kombinasi proses koagulasi dan proses AOP sistem $U V / \mathrm{H}_{2} \mathrm{O}_{2}$ sebesar $97,4 \%$. Dilihat dari efisiensi penurunan kekeruhan yang diperoleh, efisiensi penurunan nilai kekeruhan dari keseluruhan tahapan pengolahan menjadi semakin besar.

Berdasarkan hasil penelitian, pada proses AOP UV/ $\mathrm{H}_{2} \mathrm{O}_{2}$ dilakukan pemeriksaan kadar LAS pada deterjen. Kadar LAS sampel sebelum diberi perlakuan 2,659 $\mathrm{mg} / \mathrm{L}$. Nilai LAS awal pada limbah tidak melebihi baku mutu yang ditentukan pada Kep51/MENLH/10/1999, namun demikian setelah dilakukan proses koagulasi dan sistem AOP $U V / \mathrm{H}_{2} \mathrm{O}_{2}$ terjadi penurunan pada nilai LAS. Hasil pengamatan kadar LAS serta efisiensi penurunan kadar LAS dari proses koagulasi, AOP sistem $\mathrm{UV} / \mathrm{H}_{2} \mathrm{O}_{2}$ dan dari kombinasi proses koagulasi dan AOP sistem UV/ $\mathrm{H}_{2} \mathrm{O}_{2}$ disajikan dalam Tabel 4 sebagai berikut.

Tabel 4. Hasil Pengamatan Kadar LAS dari Proses Koagulasi

\begin{tabular}{ccccc}
\hline No & $\begin{array}{c}\text { Kadar LAS Sete Lah Proses } \\
\text { AOP } \\
\text { (Mg/L) }\end{array}$ & $\begin{array}{c}\text { Efisinsi Dengan } \\
\text { Proses Koagu } \\
\text { Lasi } \\
(\%)\end{array}$ & $\begin{array}{c}\text { Efisi Ensi } \\
\text { Sete Lah } \\
\text { Proses AOP } \\
\text { (\%) }\end{array}$ & $\begin{array}{c}\text { Efisi Ensi } \\
\text { Kombi Nasi } \\
\text { Pro Ses } \\
\text { Koagu Lasi } \\
\text { Dan AOP } \\
(\%)\end{array}$ \\
\hline 1 & 0,125 & 72,9 & 82,6 & 95,2 \\
2 & 0,085 & 72,9 & 88,1 & 96,8 \\
3 & 0,048 & 72,9 & 93,3 & 98,1 \\
4 & 0,106 & 72,9 & 85,2 & 96 \\
5 & 0,068 & 72,9 & 90,5 & 97,4 \\
6 & 0,073 & 72,9 & 89,8 & 97,2 \\
\hline
\end{tabular}


Berdasarkan Tabel 4 sebelum proses koagulasi ditentukan terlebih dahulu kadar LAS awal limbah cucian rumah tangga tersebut yaitu sebesar $2,659 \mathrm{mg} / \mathrm{L}$. Setelah proses koagulasi, terjadi penurunan kadar LAS yaitu sebesar $0,720 \mathrm{mg} / \mathrm{L}$. Pada tahap koagulasi mengalami penurunan kadar LAS $1,939 \mathrm{mg} / \mathrm{L}$. Setelah proses AOP kadar LAS mengalami penurunan dari $0,720 \mathrm{mg} / \mathrm{L}$ menjadi $0,073 \mathrm{mg} / \mathrm{L}$ atau sebesar $0,647 \mathrm{mg} / \mathrm{L}$ pada penambahan volume $10 \mathrm{~mL} \mathrm{H}_{2} \mathrm{O}_{2}$ pengolahan limbah cucian rumah tangga dengan kombinasi proses koagulasi dan AOP sistem UV/ $\mathrm{H}_{2} \mathrm{O}_{2}$ dapat menurunkan kadar LAS sebanyak 2,586 mg/L dari kadar awal 2,659 mg/L.

Diagram efisiensi penurunan kadar LAS dari proses koagulasi, AOP sistem UV/ $\mathrm{H}_{2} \mathrm{O}_{2}$ serta dengan kombinasi proses koagulasi dan AOP sistem $\mathrm{UV} / \mathrm{H}_{2} \mathrm{O}_{2}$. disajikan pada Gambar 2 .

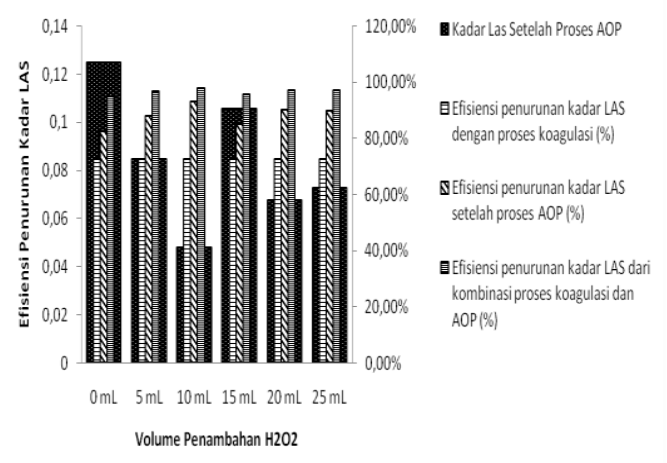

Gambar 2. Diagram Efisiensi Penurunan Kadar LAS dari Proses Koagulasi

Berdasarkan Gambar 2, hasil pemeriksaan kadar LAS dari proses AOP sistem UV/ $\mathrm{H}_{2} \mathrm{O}_{2}$ terjadi penurunan pada penambahan $\mathrm{H}_{2} \mathrm{O}_{2}$ dengan volume $10 \mathrm{~mL}$, sehingga penambahan volume optimum untuk menurunkan kadar LAS pada penelitian ini adalah $10 \mathrm{~mL}$. Efisiensi penurunan kadar LAS setelah proses koagulasi, AOP dan dari kombinasi proses koagulasi dan AOP sistem $\mathrm{UV} / \mathrm{H}_{2} \mathrm{O}_{2}$ pengolahan berturu-turut sebesar $72,9 \%, 93,3 \%$ dan $98,1 \%$.

Hasil pengamatan untuk nilai fosfat sebelum dilakukan perlakukan yaitu sebesar 0,988 $\mathrm{mg} / \mathrm{L}$. Nilai fosfat awal pada limbah tidak melebihi baku mutu yang ditentukan pada Kep51/MENLH/10/1999, namun demikian setelah dilakukan proses koagulasi dan sistem AOP $\mathrm{UV} / \mathrm{H}_{2} \mathrm{O}_{2}$ terjadi penurunan pada nilai fosfat. Hasil pengamatan kadar fosfat serta efisiensi penurunan kadar fosfat dari proses koagulasi, sistem AOP $\mathrm{UV} / \mathrm{H}_{2} \mathrm{O}_{2}$ dan dari keseluruhan tahapan pengolahan ini yang disajikan dalam Tabel 5

Tabel 5. Hasil Pengamatan Kadar Fosfat dari Proses Koagulasi

\begin{tabular}{ccccc}
\hline No & $\begin{array}{c}\text { Kadar Fosfat Setelah Proses } \\
\text { AOP } \\
(\mathbf{M g} / \mathbf{L})\end{array}$ & $\begin{array}{c}\text { Efisi Ensi } \\
\text { Deng An Pro } \\
\text { Ses Koagu } \\
\text { Lasi } \\
(\%)\end{array}$ & $\begin{array}{c}\text { Efisiensi } \\
\text { Setelah Proses } \\
\text { AOP } \\
(\%)\end{array}$ & $\begin{array}{c}\text { Efisi Ensi } \\
\text { Kombi Nasi } \\
\text { Pro Ses } \\
\text { Koagulasi } \\
\text { Dan AOP } \\
(\%)\end{array}$ \\
\hline 1 & 0,009 & 89,2 & 91,5 & 99,0 \\
2 & 0,008 & 89,2 & 92,4 & 99,1 \\
3 & 0,004 & 89,2 & 96,2 & 99,5 \\
4 & 0,011 & 89,2 & 89,6 & 98,8 \\
5 & 0,006 & 89,2 & 94,3 & 99,3 \\
6 & 0,010 & 89,2 & 90,5 & 98,9 \\
\hline
\end{tabular}

Berdasarkan Tabel 5, sebelum proses koagulasi, ditentukan terlebih dahulu kadar fosfat awal limbah cucian rumah tangga tersebut yaitu sebesar $0,988 \mathrm{mg} / \mathrm{L}$. Setelah proses koagulasi, terjadi penurunan kadar fosfat yaitu sebesar $0,106 \mathrm{mg} / \mathrm{L}$. Pada tahap koagulasi mengalami penurunan kadar fosfat $0,882 \mathrm{mg} / \mathrm{L}$. Setelah proses AOP kadar fosfat mengalami penurunan dari $0,106 \mathrm{mg} / \mathrm{L}$ menjadi $0,004 \mathrm{mg} / \mathrm{L}$ atau turun sebesar $0,102 \mathrm{mg} / \mathrm{L}$ pada 
penambahan volume $10 \mathrm{~mL} \mathrm{H}_{2} \mathrm{O}_{2}$ pengolahan limbah cucian rumah tangga dengan kombinasi proses koagulasi dan AOP sistem UV/ $\mathrm{H}_{2} \mathrm{O}_{2}$ dapat menurunkan kadar fosfat sebanyak 0,984 $\mathrm{mg} / \mathrm{L}$ dari kadar awal $0,988 \mathrm{mg} / \mathrm{L}$.

Efisiensi penurunan kadar fosfat dari proses koagulasi, AOP sistem UV/ $\mathrm{H}_{2} \mathrm{O}_{2}$ dan dengan kombinasi proses koagulasi dan AOP sistem UV/ $\mathrm{H}_{2} \mathrm{O}_{2}$ disajikan pada Gambar 3.

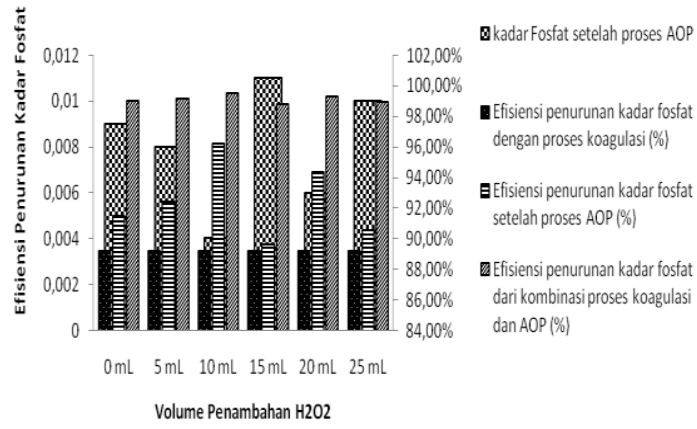

\section{Gambar 3. Diagram Efisiensi Penurunan Kadar Fosfat dari Proses Koagulasi}

Dilihat dari Gambar 3, hasil pemeriksaan kadar fosfat setelah diberi perlakuan dengan proses AOP sistem UV/ $\mathrm{H}_{2} \mathrm{O}_{2}$ terjadi penurunan pada penambahan $\mathrm{H}_{2} \mathrm{O}_{2}$ dengan volume $10 \mathrm{~mL}$, sehingga penambahan volume optimum untuk menurunkan kadar fosfat pada penelitian ini adalah $10 \mathrm{~mL}$. Efisiensi penurunan kadar fosfat setelah proses koagulasi, AOP dan dari kombinasi proses koagulasi dan AOP sistem $\mathrm{UV} / / \mathrm{H}_{2} \mathrm{O}_{2}$ berturu-turut sebesar $\quad 89,2 \%, 96,2 \%$ dan $99,5 \%$.

Proses AOP UV/ $\mathrm{H}_{2} \mathrm{O}_{2}$ ini dilakukan dalam suasana asam dalam kondisi optimum yaitu $\mathrm{pH} 3$, reagen yang digunakan yaitu $\mathrm{H}_{2} \mathrm{SO}_{4}$. Hal ini berdasarkan penelitian yang dilakukan Tedy yaitu foto-oksidasi $\mathrm{UV} / \mathrm{H}_{2} \mathrm{O}_{2}$ untuk pengolahan zat warna DYA pada industri tekstil nonbiodegradasi dengan multi-lamp buble column photoreaktor yang menyatakan kondisi optimum yaitu pada $\mathrm{pH}$ 3. Selain itu digunakannya $\mathrm{pH} 3$ karena proses AOP hanya dapat berlangsung dalam suasana asam. Hal ini dikarenakan dengan semakin kecilnya $\mathrm{pH}$, semakin banyak ion $\mathrm{H}^{+}$ yang dapat berikatan dengan radikal $\mathrm{O}_{2}^{-\cdot}$ membentuk $\mathrm{H}_{2} \mathrm{O}_{2}$ (Tedy, 2011. dalam Novi 2013).

Hasil penelitian didapatkan bahwa efisiensi penurunan nilai kekeruhan, kadar LAS dan fosfat mencapai $98 \%$. Hal ini menunjukkan bahwa pengolahan limbah dengan menggunakan proses koagulasi dikombinasikan dengan proses AOP sistem $\mathrm{UV} / \mathrm{H}_{2} \mathrm{O}_{2}$ sangat efektif dalam menurunkan kadar LAS dan fosfat pada proses pengolahan limbah cucian rumah tangga. Untuk penurunan nilai kekeruhan dari proses AOP sistem UV/ UV/ $\mathrm{H}_{2} \mathrm{O}_{2}$ lebih rendah dibandingkan dengan proses koagulasi. Pada proses AOP sistem UV/ $U V / \mathrm{H}_{2} \mathrm{O}_{2}$ dapat menurunkan nilai kekeruhan hingga $72.5 \%$.

\section{Simpulan dan Saran}

Berdasarkan hasil penelitian yang telah dilakukan, maka beberapa simpulan yang dapat diperoleh adalah sebagai berikut: 1) Kondisi optimum pada proses koagulasi untuk pengolahan limbah cucian rumah tangga dengan koagulan feri klorida $\left(\mathrm{FeCl}_{3}\right)$ pada $\mathrm{pH} 4$ dan konsentrasi koagulan $25 \mathrm{~mL}$. Efisiensi penurunan kekeruhan pada kondisi tersebut adalah $90,7 \%$; 2) Efisinsi penurunan nilai kekeruhan, kadar LAS dan fosfat dari sistem AOP UV/ $\mathrm{H}_{2} \mathrm{O}_{2}$ berturut-turut adalah $72,5 \%$, 93,3\% dan 96,2\%; 3) Efisiensi penurunan nilai kekeruhan, kadar LAS dan fosfat dari kombinasi proses koagulasi dan AOP sistem $U V / \mathrm{H}_{2} \mathrm{O}_{2}$ berturut-turut sebesar $97,4 \%, 98,1 \%$ dan $99,5 \%$

Berdasarkan penelitian ini perlu dilakukan penelitian lebih lanjut mengenai penurunan kekeruhan dan kadar deterjen dengan bahan dasar LAS (Linier Alkyl Benzene Sulfonate) dan fosfat dengan proses koagulasi dan proses AOP Sistem $U V / \mathrm{H}_{2} \mathrm{O}_{2}$, dengan penambahan parameter seperti $\mathrm{pH}$ dan suhu untuk meningkatkan daya efisinsi maksimum. 


\section{Daftar Pustaka}

Adhitiastuti. Heryani.2008. Pengolahan Limbah Deterjen Sintetik Dengan Trickling Filter.Semarang. Jurusan Teknik Kimia Fakultas Teknik Universitas Diponegoro.

Anton,Selamet .2008. Metode Pengolahan Deterjen. http://.wordpress.com (diakses tanggal 6 September 2013).

Aryanti,Eka.2009 Komposisi Deterjen. Bandung.Jurusan Teknologi Pertanian. Institut Pertanian Bogor.

Egar. A. 2011. Fosfat Penyabab Eutrofikasi. Surabaya. Jurusan Teknik Kimia. FTI UPN Jatim.

Golean.B.A.2013. Koagulasi dan Flokulasi.Malang. Jurusan Kimia. FMIPA.Universitas Negeri Malang.

Hardi,Maulana. 2003. Pengolahan Limbah Deterjen. Jakarta .Studi IImu Lingkungan Program Pascasarjana. Universitas Airlangga.

Heryani. A, Puji, H. 2008. Pengolahan Limbah Deterjen Sintetik (Makalah Penelitian) http://eprints.undip.ac.id ( Diakses tanggal 2 September 2013)

Jhonatan, scheibel.2009. Metode Koagulasi Limbah. Departemen Teknik Kimia, FakultasTeknik-Universitas Indonesia: Depok dan jurusan Teknik Kimia, Fakultas Teknik Universitas Sultan ageng Tirtayasa.

Kasiana .Indah. 2013. Mengetahui Dampak Air Limbah Deterjen Terhadap Organisme. http://tutorjunior.blogspot.com (Diakses tanggal 2 September 2013).

Kurniati,Elly. 2009. Penurunan Konsentrasi Deterjen Pada Limbah deterjen dengan Metode Pengendapan Menggunakan $\mathrm{FeCl}_{3}$. Surabaya. Jurusan Teknik Kimia. FTI UPN "Veteran" Jatim.

Marurung, Jeolin. 2009. Studi Efek Jenis dan Berat Koagulan Terhadap Penurunan Nilai Kekeruhan Pada Pengolahan Air Limbah Deterjen Dengan Cara Koagulasi. Skripsi. Fakultas MIPA Uniuversitas Sumatra Utara. Medan.

Nurhayati. 2009. Pengolahan Limbah Deterjen dengan Biofilter. http://www.greenradio.com. ( Diakses tanggal 29Agustus 2013).

Peraturan Menteri Lingkungn Hidup No. 112 Tahun 2003. Tentang Air Limbah Domestik Air Limbah yang Berasal Dari Usaha dan Atau Kegiatan Pemukiman, Rumah Makan, Perkantoran, Aparteman dan Asrama.

Puspitasari, Dyah Pratama.2006. Adsorpsi surfaktan Anionik pada berbagai pH Menggunakan Karbon Aktif Termodifikasi Zink Klorida. Skipsi. Departemen Kimia Fakultas MIPA Institut Pertanian Bogor: Bogor.

Retnaningdyah,c.,s. Samino, Suharjono, I. Doddy dan Prayitno, 2009. Uji Toksitas Akut Surfaktan Deterjen (LAS dan ABS) terhadap Beberapa Sungai. Jakarta. Jurusan Teknik Kimia. Fakultas Tenik Universitas Indonesia.

Rochman, Faidur.2009. Pembuatan Ipal Mini Untuk Limbah Deterjen Domestik. (Makalah Penelitian) http://eprints.undip.ac.id ( Diakses tanggal 2 Maret 2014)

Rosariawari, Fira. 2009. Efektifitas Multivalen Metal Ions Dalam Penurunan Kadar Pospat Sebagai Bahan Pembentuk Deterjen. Surabaya. Progdi Teknik Lingkungan, Fakultas Teknik Sipil dan Pencemaran. Universitas Pembangunan Nasional. 
Sigid, hariyadi. 2004. Parameter Pencemaran Air Dan Baku Mutu Air Limbah. Jakarta. Jurusan Teknik Lingkungan. Universitas Indonesia.

Sopiah. R. Nida. 2009. Laju Degradasi Surfaktan Linear Alkil Benzena Sulfonat (LAS) Pada Limbah Deterjen Secara Anaerob. Jakarta. Balai Teknologi Lingkungan Badan Pengkajian dan Penerapan Teknologi.

Soekidjo Notoatmojo. 2007. Bahan Penyabab Kekeruhan. Jakarta. Jurusan Teknik Kimia. Fakultas Tenik Universitas Indonesia

Sunan., Kustiningsih, I.,Jayanudin, Usmanizar,D.,Yulianti, E.2009. Degradasi dengan metode fotokatalisis menggunakan reaktor Annular Uv-C.Cilegon. Departemen Teknik Kimia, Fakultas Teknik-Universitas Indonesia: Depok dan jurusan Teknik Kimia, Fakultas Teknik Universitas Sultan ageng Tirtayasa.

Tresna dewi, Novi. 2013. Penurunan kekeruhan dan fenol pada limbah industri tekstil dengan sistem fotokimia $\mathrm{UV} / \mathrm{H}_{2} \mathrm{O}_{2}$. Tugas Akhir.Singaraja. jurusan Analis kimia. FMIPA.Universitas Pendidikan Ganesha.

Yuliati,Suci.2006. Proses koagulasi-Flokulasi Pada Pengolahan Tersier limbah Cair PT. Capsugel Indonesia. Bogor. Fakultas Teknologi Pertanian. Institut Pertanian Bogor. 